ITEJ Desember-2019, Volume 4 Nomor 2 Page 67 - 74

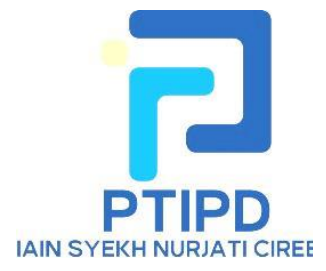

ITEJ

Information Technology Engineering Journals eISSN : 2548-2157

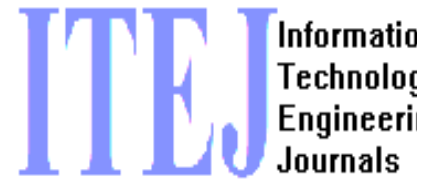

Url : https://syekhnurjati.ac.id/journal/index.php/itej

Email : itej@syekhnurjati.ac.id

\title{
The Influence of Android-Based Mobile Learning on Students' Learning Independence on the Subject of Derivative Algebraic Functions
}

\author{
Siti Kurniasih \\ Tadris Matematika \\ IAIN Syekh Nurjati \\ Cirebon
}

\author{
Darwan \\ Tadris Matematika \\ IAIN Syekh Nurjati \\ Cirebon \\ darwan@syekhnurjati.ac.id
}

\author{
Arif Muchyidin \\ Tadris Matematika \\ IAIN Syekh Nurjati \\ Cirebon
}

\begin{abstract}
The purpose of this research are: 1) to find out how much student's self regulated learning in using android-based mobile learning, 2) to determine students' responses about the using of android-based mobile learning in mathematics learning, and 3) to determine whether or not there is an influence of android-based mobile learning on students' self regulated learning. Metodology in this research is using the experimental method with data collection techniques in the form of questionnaires for the two variables. The population in this research are all students of the clas XI Science in SMAN 1 Astanajapura, while the research sample is XI Science 4 class which was selected using cluster random sampling technic. Based on the results of the research, it can be concluded that the results of the student response questionnaire in using android-based mobile learning show strong criteria with an average percentage of $70.7 \%$ and the results of the students' self regulated learning questionnaire show strong criteria with an average percentage of 73.7\%. After hypothesis testing with $\alpha=0.05$, it can be seen that the value of $t_{\text {count }}>t_{\text {table }}$ is $4.528>1.701$. Because $t_{\text {count }}>t_{\text {table }}$ then $H_{o}$ is rejected and $H_{a}$ is accepted, meaning that there is a significant influence between the using android-based mobile learning on students' self regulated learning. The magnitude of the coefficient of determination obtained is 0.423 or $42.3 \%$ which means that the using of android-based mobile learning has an effect of $42.3 \%$ on students' self regulated learning and the rest in influenced by other factors.
\end{abstract}

Keywords: Instructional Media, Android-Based Mobile Learning, Self Regulated Learning.

\section{Pendahuluan}

Pendidikan merupakan salah satu komponen penting untuk mencetak generasi muda yang cerdas dan memiliki beragam keterampilan. Keberhasilan suatu pendidikan tidak terlepas dari keberhasilan dalam proses pembelajaran yang telah dilakukan, karena dalam proses pembelajaran itulah siswa mengalami perkembangan baik dalam hal pengetahuan ataupun kepribadian. Proses pembelajaran dalam satuan pendidikan harus dilakukan 
secara interaktif, inspiratif, menyenangkan, menantang, memotivasi peserta didik untuk ikut berpartisipasi secara aktif, serta memberikan kesempatan pada peserta didik untuk mengembangkan ide, kreativitas, kemandirian, minat dan perkembangan fisik serta psikologis yang dimiliki oleh dirinya [1].

Pembelajaran merupakan suatu kegiatan mentransfer ilmu yang dimiliki oleh pendidik kepada peserta didiknya. Pembelajaran pada dasarnya merupakan interaksi antara sumber belajar, pendidik dan peserta didik [1]. Interaksi komunikasi yang dimaksud dapat dilakukan dengan cara bertatap muka langsung atau tidak langsung yakni dengan menggunakan media. Dalam proses pembelajaran ada lima komponen yang harus diperhatikan oleh seorang guru ketika akan melakukan suatu pembelajaran yakni: tujuan, meteri, startegi, media dan evaluasi.

Untuk mencapai tujuan pembelajaran secara optimal seorang guru memang berperan penting di dalamnya baik dalam hal mendesain pembelajaran maupun pengelolaan kelas dikarenakan seorang guru memiliki lebih banyak pengetahuan dan pengalaman, akan tetapi eksistensi atau peran siswa juga turut aktif dalam ketercapaian tujuan pembelajaran tersebut. Salah satu sikap yang harus dimiliki oleh siswa yakni kemandirian dalam belajar, dengan kemandirian belajar yang tinggi siswa tidak akan menunggu guru menunjuk dirinya untuk maju mengerjakan soal melainkan mengajukan dirinya secara suka rela untuk maju mengerjakan soal. Hal tersebut sesuai dengan pendapat Hidayati \& Listyani yang menyatakan bahwa salah satu ciri kemandirian belajar siswa yakni melakukan sesuatu berdasarkan keinginannya sendiri [2].

Kemandirian balajar merupakan suatu sikap siswa yang memiliki inisiatif sendiri untuk belajar, memiliki keinginan untuk menguasai kompetensi, memiliki rasa percaya diri dan juga tanggung jawab terhadap tugasnya sebagai peserta didik serta tidak bergantung pada orang lain. Hal ini sejalan dengan pendapat Fidiana dkk yang mengatakan bahwa kemandirian belajar siswa adalah keadaan siswa yang dapat memecahkan masalah dalam pembelajaran yang ia lakukan dengan kemampuan dan inisiatifnya sendiri serta bertanggung jawab melalui strategi belajar tertentu kemudian dengan rasa percaya diri menemukan pemecahan dari masalahnya tanpa bantuan orang lain [3].

Berdasarkan hasil observasi di SMA Negeri 1 Astanajapura diketahui bahwasannya dalam proses pembelajaran siswa masih begitu pasif proses pembelajaran masih didominasi oleh guru sehingga dapat membuat siswa mudah merasa jenuh, siswa tidak memiliki inisiatif untuk maju mengerjakan soal di depan kelas mereka selalu merasa bahwa jawaban yang diperolehnya tidaklah benar, bahkan ketika guru menunjuk salah satu siswa untuk maju mengerjakan soal masih saja ada siswa yang enggan untuk maju serta masih terdapat banyak siswa yang mencontek tugas yang diberikan. Hal ini menunjukkan rendahnya tingkat kemandirian belajar yang dimiliki oleh siswa, mengingat begitu pentingnya peran kemandirian belajar maka dibutuhkan sebuah inovasi dalam proses pembelajaran.

Media pembelajaran merupakan salah satu komponen yang mendukung proses berlangsungnya pembelajaran, membuat proses pembelajaran tidak belangsung secara monoton yang mengakibatkan siswa malas untuk mengikuti proses pembelajaran [4]. Seiring berkembangnya teknologi media bukan saja sebagai alat bantu yang dapat membantu dan mempermudah guru dalam menyampaikan materi akan tetapi media pembelajaran juga harus dapat memotivasi dan membangun keinginan siswa untuk belajar. Media pembelajaran yang dapat membantu siswa untuk meningkatkan kemandirian belajar salah satu contohnya yaitu media pembelajaran yang memanfaatkan fungsi smarthphone. Smartphone merupakan salah satu alat teknologi yang bersifat kekinian yang hampir dimiliki oleh semua siswa terlebih untuk siswa di jenjang sekolah menengah atas. Smartphone memiliki berbagai macam fungsi yang dapat memudahkan para penggunanya baik dalam hal menjalin komunikasi ataupun memperoleh informasi. Media pembelajaran yang memanfaatkan fungsi smartphone atau dapat disebut mobile 
learning disinyalir dapat meningkatkan kemandirian siswa dalam belajar karena mobile learning dapat memfasilitasi siswa untuk belajar kapanpun dan di manapun.

Mobile learning memungkinkan siswa untuk belajar secara mandiri, mempelajari materi yang belum atau tidak tersampaikan oleh guru karena keterbatasan waktu pelajaran di sekolah. Mobile learning dapat menjadi suplemen tambahan untuk siswa dalam memahami materi, karena mobile learning memanfaatkan smartphone yang mudah dan praktis untuk dibawa kemanapun serta memberikan kondisi belajar yang berbeda.

Mobile learning yang digunakan memanfaatkan smartphone berbasis Android karena smartphone jenis ini banyak digunakan. Berdasarkan penelitian Nielsen yang merupakan perusaahan di bidang informasi global meyatakan bahwa smartphone jenis Android memiliki persentase jumlah penjualan tertinggi yaitu 53\% dibanding smartphone jenis lain yang sedang berkembang seperti Blackberry dengan persentase 0,5\%, Apple dengan persentase 45\% dan Windows Phone dengan persentase 1,5\% [5]. Selain itu Millenial Media yang merupakan salah satu perusahaan media menyebutkan bahwa pada akhir tahun 2011 Android merupakan sistem operasi mobile yang paling banyak digunakan dengan persentase 56\%, kemudian iOS (produksi dari Apple Inc.) 28\%, RIM (Blackberry) $13 \%$, Symbian 1\%, Windows $1 \%$, dan sistem operasi mobile lainnya $1 \%$ [6].

Berdasarkan permasalahan yang telah diuraikan, penulis tertarik untuk melakukan penelitian tentang pengaruh mobile learning berbasis android terhadap kemandirian dengan judul penelitian "Pengaruh Mobile Learning Berbasis Android Terhadap Kemandirian Belajar Siswa Pada Pokok Bahasan Turunan Fungsi Aljabar".

\section{LANDASAN TEORI}

\section{A. Mobile Learning}

Istilah mobile learning merujuk pada pemanfaatan perangkat teknologi seperti: Personal Digital Assistants (PDAs), telepon genggam atau ponsel, tablet, dan laptop yang digunakan dalam proses pembelajaran. Menurut Tella (2003) mobile learning merupakan suatu perangkat yang dapat digunakan untuk meningkatkan pertumbuhan kognitif dan motivasi yang dimiliki oleh individu ketika individu tersebut dalam proses perkembangan berdasarkan kebutuhan dan konteks. Salah satu konteksnya yakni perkembangan ilmu pengetahuan yang dimiliki oleh individu tersebut. Sedangkan menurut Sharples (2000) mobile learning merupakan suatu perangkat yang dapat digunakan dalam proses pembelajaran yang dapat memungkinkan peserta didik untuk belajar di manapun mereka berada baik secara pribadi maupun berkelompok sehingga pembelajaran itu bermakna.[7]

Mobile learning merupakan suatu pembelajaran yang memanfaatkan teknologi informasi dan komunikasi dengan cara menyediakan materi ajar yang dapat diakses di manapun dan kapanpun peserta didik berada, sehingga dengan meggunakan mobile learning tersebut peserta didik menjadi memiliki banyak waktu luang untuk mengakses materi di luar jam pembelajaran sekolah [8].

Dari beberapa pendapat tersebut, dapat disimpulkan bahwa mobile learning merupakan suatu pembelajaran yang memanfaatkan fungsi perangkat mobile terutama ponsel dalam suatu proses pembelajaran. Selain itu dengan menggunakan mobile learning peserta didik memiliki banyak kesempatan untuk mempelajari materi di manapun dan kapanpun baik belajar sendiri maupun berkelompok. Tujuan dari penggunaan mobile learning yakni memberikan kemudahan bagi siswa untuk mengakses materi dengan tampilan yang menarik baik di jam pelajaran maupun di luar jam pelajaran dengan memanfaatkan ponsel yang dimiliki oleh setiap siswa sehingga siswa lebih termotivasi untuk belajar. Selain itu mobile learning juga memberikan suasana dan pengalaman belajar yang baru bagi siswa. Mobile learning memiliki beberapa kelebihan yaitu [9]:

1. Membantu siswa untuk meningkatkan kemampuan yang dimilikinya.

2. Menguatkan pembelajaran individual atau kolaboratif. 
3. Membantu siswa untuk mengidentifikasi area ketika mereka membutuhkan bimbingan dan dukungan.

4. Membantu menjembatani kesenjangan antara ponsel dan teknologi informasi dan komunikasi.

5. Membantu siswa dalam proses pembelajaran dan mengatur tingkat ketertarikan mereka.

6. Membantu siswa untuk tetap fokus dalam periode waktu yang lebih lama.

7. Membantu meningkatkan apresiasi pada siswa.

8. Membantu meningkatkan rasa percaya diri yang dimiliki oleh siswa.

\section{B. Android}

Android merupakan operasi sistem yang sering digunakan di berbagai macam smartphone, selain itu android juga telah digunakan pada tablet, netbook, MP4 player, dan TV internet. Android adalah sebuah sistem operasi perangkat mobile berbasis linux yang mencakup sistem operasi, middleware, dan aplikasi. Pada awalnya android dikembangkan oleh Android Inc. yang didirikan oleh Andy Rubin, Rich Miner, Nick Sears dan Chris White pada bulan Oktober 2003 di Palo Alto California untuk mengembangkan sebuah perangkat mobile yang lebih peka dan mengerti penggunanya. Kemudian pada bulan Agustus 2005 sebuah perusahaan raksasa yaitu Google mengakuisi Android Inc. sebagai anak perusahaannya secara utuh [10].

Android merupakan suatu platform yang mencakup keseluruhan dari sistem operasi sampai pada aplikasi yang berjalan dan semuanya bersifat open-source. Android yang bersifat open-source ini memudahkan para pengembang untuk membuat aplikasi sesuai dengan keinginannya, bahkan para pengembang dapat menjual aplikasi yang dibuat tanpa harus membayar lisensi ke produsen atau vendor tertentu [6]. Kemudian untuk mengembangkan android dibentuklah Open Handset Alliance, konsorsium dari 34 perusahaan peranti keras, peranti lunak, dan telekomunikasi, termasuk Google, HTC, Intel, Motorola, Qualcomm, T-Mobile, dan Nvidia [11].

\section{Kemandirian Belajar}

Kemandirian belajar merupakan sikap seorang siswa yang memiliki kesadaran untuk melakukan kegiatan belajar secara mandiri tanpa bantuan orang lain [12]. Siswa akan belajar dengan inisiatif sendiri tanpa menunggu perintah dari orang lain serta bertanggung jawab atas keputusan yang telah diambilnya. Kemandirian belajar merupakan sikap yang dimiliki oleh siswa yang dapat dilihat dari keinginannya untuk melakukan belajar mandiri tanpa bergantung pada orang lain, dapat mengetahui cara belajar yang efektif untuk dilakukannya serta dapat menyelesaikan tugas-tugas secara mandiri [13]. Dapat disimpulkan bahwa kemandirian belajar merupakan sikap seorang siswa yang memiliki keinginan untuk belajar tanpa menunggu perintah dari orang lain, memiliki kesadaran akan tanggung jawabnya sebagai seorang pelajar serta memiliki kepercayaan diri terhadap kemampuan yang dimilikinya. Kemandirian belajar merupakan sikap yang harus dimiliki oleh siswa sehingga siswa dapat mengembangkan kemampuan diri secara optimal tanpa bergantung pada orang lain.

Ciri-ciri siswa yang memiliki kemandirian belajar menurut Sardiman diantaranya yaitu [14]:

1. Memiliki kecenderungan untuk berpendapat, berperilaku dan bertindak sesuai dengan kehendaknya sendiri.

2. Memiliki keinginan yang kuat untuk mencapai tujuan.

3. Membuat perancanaan dan berusaha dengan tekun untuk mewujudkan harapannya.

4. Mampu untuk berpikir dan bertindak secara kreatif, penuh inisiatif serta tidak hanya sekedar meniru.

5. Memiliki kecenderungan untuk mencapai suatu kemajuan, seperti keinginan untuk meningkatkan prestasi belajar. 
6. Mampu menemukan sendiri sesuatu yang harus dilakukan tanpa mengharapkan bimbingan dan pengarahan dari orang lain.

Adapun indikator dari kemandirian belajar yaitu sebagai berikut [2]:

1. Ketidaktergantungan terhadap orang lain

2. Memiliki kepercayaan diri

3. Berperilaku disiplin

4. Memiliki rasa tanggung jawab

5. Berperilaku berdasarkan inisiatif sendiri

6. Melakukan kontrol diri

\section{A. Metode dan Desain Penelitian}

\section{Metodologi Penelitian}

Metode penelitian yang digunakan dalam penelitian ini yaitu metode eksperimen. Penelitian eksperimen adalah suatu penelitian yang digunakan untuk mencari pengaruh variabel independen terhadap variabel dependen dalam kondisi yang terkendalikan [15]. Desain penelitian yang digunakan dalam metode eksperimen ini yaitu One-Shot Case Study. Desain ini hanya menggunakan satu kelas sebagai kelas eksperimen yang mendapatkan perlakuan khusus [15]. Perlakuan khusus dalam penelitian ini yaitu penggunaan mobile learning berbasis android dalam pempelajaran matematika. Bentuk desain eksperimen One-Shot Case Study dalam penelitian ini dapat digambarkan sebagai berikut:

\begin{tabular}{ll|}
\hline $\mathrm{X}$ & $\mathrm{O}$ \\
\hline
\end{tabular}

$$
\begin{aligned}
& \text { Keterangan: } \\
& \mathrm{X}=\text { perlakuan yang diberikan } \\
& \mathrm{O}=\text { hasil observasi setelah adanya perlakuan }
\end{aligned}
$$

\section{B. Populasi dan Sampel}

Populasi adalah wilayah generalisasi yang terdiri dari obyek/subyek yang mempunyai kualitas dan karakteristik tertentu yang ditetapkan oleh peneliti untuk dipelajari dan kemudian ditarik kesimpulannya [15]. Populasi dalam penelitian ini yaitu seluruh siswa kelas XI di SMA Negeri 1 Astanajapura. Sampel adalah bagian dari jumlah dan karakteristik yang dimiliki oleh populasi tersebut [15]. Teknik pengambilan sampel yang digunakan dalam penelitian ini adalah Cluster Random Sampling, yaitu teknik pengambilan sampel dari anggota populasi secara acak tanpa memperhatikan strata (tingkatan) dalam anggota populasi tersebut [15]. Sampel dalam penelitian ini yaitu siswa kelas XI IPA 4 di SMA Negeri 1 Astanajapura.

\section{Instrumen Penelitian}

Instrumen penelitian yang digunakan dalam penelitian ini yaitu angket/kuesioner. Angket merupakan teknik pengumpulan data yang dilakukan dengan cara memberikan beberapa pertanyaan atau pernyataan yang telah disusun sebelumnya secara tertulis kepada responden untuk dijawabnya yang digunakan untuk mendapatkan informasi berkaitan dengan pendapat, aspirasi, persepsi, keinginan, keyakinan, dan lain-lain [16]. Angket yang digunakan dalam penelitian ini adalah untuk mengetahui tingkat kemandirian belajar siswa dan respon siswa terhadap pembelajaran dengan menggunakan mobile learning dalam pembelajaran matematika. Angket yang dibuat menggunakan model angket skala Likert dengan lima alternatif jawaban yaitu: Sangat Setuju (SS), Setuju (S), Kurang Setuju(KS), Tidak Setuju (TS), Sangat Tidak Setuju (STS). 


\section{HaSil dan PeMbahasan}

Penelitian ini menggunakan dua angket yang berbeda yakni angket respon siswa terhadap penggunaan mobile learning berbasis android dan angket kemandirian siswa yang kemudian disebarkan pada kelas XI IPA 4 sebagai kelas eksperimen yang berjumlah 30 siswa.

Angket respon siswa terhadap penggunaan mobile learning berbasis android setelah disebarkan memperoleh hasil yang dapat dilihat pada gambar di bawah ini:

Berdasarkan Gambar 1 dapat dilihat persentase dari angket respon siswa terhadap penggunaan mobile learning berbasis android tiap indikatornya. Secara keseluruhan angket respon siswa memperoleh persentase rata-rata sebesar $70.7 \%$ yang termasuk ke dalam kategori kuat.

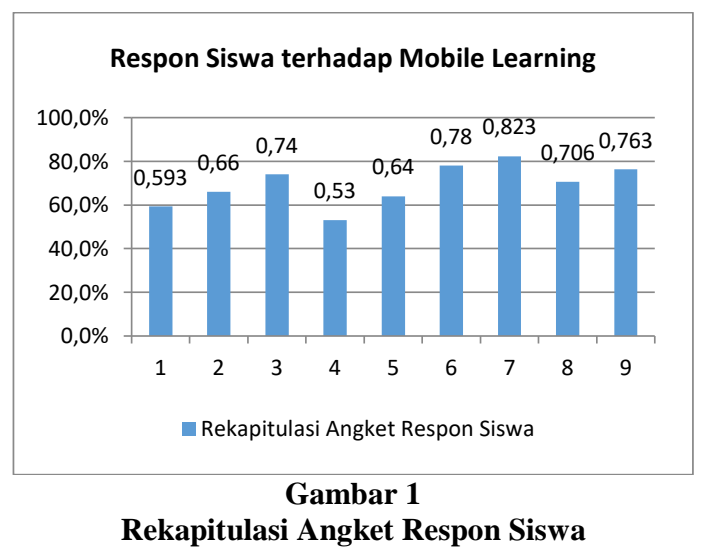

Angket kemandirian belajar siswa setelah disebarkan memperoleh hasil yang dapat dilihat pada gambar di bawah ini:

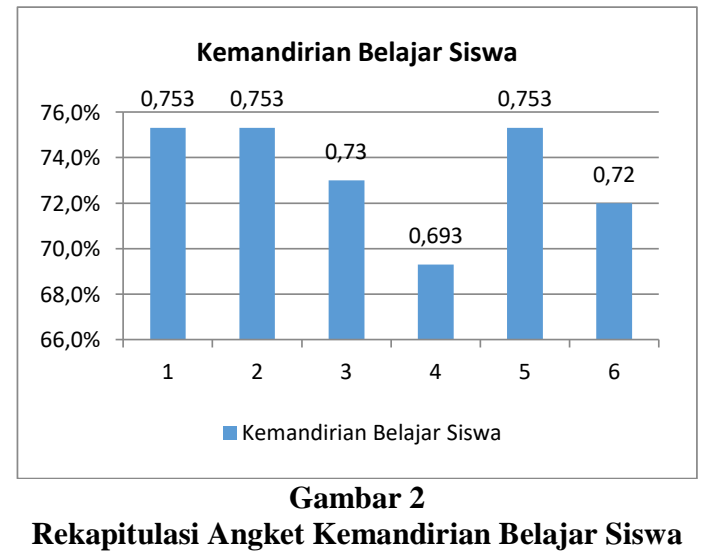

Berdasarkan Gambar 2 dapat dilihat persentase dari angket kemandirian belajar siswa tiap indikatornya. Secara keseluruhan angket kemandirian belajar siswa memperoleh persentase rata-rata sebesar $73.3 \%$ yang termasuk ke dalam kategori kuat.

Berdasarkan hasil penelitian yang dilakukan di SMA Negeri 1 Astanajapura, menunjukkan bahwa respon siswa terhadap penggunaan mobile learning berbasis android tergolong kuat denga persentase rata-rata sebesar 70.7\%. Kemandirian belajar siswa juga tergolong kuat dengan persentase rata-rata sebesar $73.7 \%$. Hal itu didapat setelah peneliti menganalisis butir-butir pernyataan dari dua jenis angket tersebut.

Berdasarkan hasil uji hipotesis penelitian menggunakan program SPSS 20 diperoleh nilai $t_{\text {hitung }}$ sebesar 4.528 dan $t_{\text {tabel }}$ sebesar 1.701 yang berarti $4.528>1.701$ atau nilai $t_{\text {hitung }}>t_{\text {tabel }}$, maka $H_{o}$ ditolak dan $H_{a}$ diterima. Artinya, terdapat pengaruh penggunaan mobile learning berbasis android terhadap kemandirian belajar siswa di kelas XI SMA Negeri 1 Astanajapura. 
Setelah diketahui bahwa terdapat pengaruh antara penggunaan mobile learning berbasis android terhadap kemandirian belajar siswa, maka langkah selanjutnya adalah mengukur seberapa besar pengaruh penggunaan mobile learning berbasis android terhadap kemandirian belajar siswa. Berdasarkan hasil perhitungan uji koefisien determinasi diperoleh nilai sebesar 0.423 atau $42.3 \%$, yang artinya bahwa mobile learning berbasis android memiliki pengaruh sebesar $42.3 \%$ terhadap kemandirian belajar siswa, sedangkan sisanya yaitu $57.7 \%$ dipengaruhi oleh faktor lain.

\section{KeSIMPUlan}

Berdasarkan data yang telah di dapat dan dikumpulkan kemudian dianalisis dengan menggunakan beberapa teknik dalam penelitian yang telah dibahas dalam bab sebelumnya, maka dapat ditarik kesimpulan sebagai berikut:

1. Respon siswa terhadap penggunaan mobile learning berbasis android di kelas XI SMA Negeri 1 Astanajapura secara keseluruhan memberikan reaksi positif. Hal ini dapat dilihat dari perolehan persentase rata-rata angket respon siswa terhadap penggunaan mobile learning berbasis android sebesar $78 \%$ yang menunjukkan kriteria kuat.

2. Kemandirian belajar siswa di kelas XI SMA Negeri 1 Astanajapura yang secara keseluruhan memperoleh persentase rata-rata sebesar $76 \%$ yang menunjukkan kriteria kuat.

3. Berdasarkan hasil uji hipotesis, dapat diketahui bahwa nilai $t_{\text {hitung }}>t_{\text {tabel }}$ yaitu $4.528>1.701$. Karena $t_{\text {hitung }}>t_{\text {tabel }}$, maka $H_{o}$ ditolak dan $H_{a}$ diterima. Artinya, terdapat pengaruh yang signifikan antara mobile learning berbasis android terhadap kemandirian belajar siswa. Berdasarkan uji koefisien determinasi diperoleh nilai sebesar 0.423 atau $42.3 \%$, yang artinya bahwa mobile learning berbasis android berpengaruh sebesar $42.3 \%$ terhadap kemandirian belajar siswa sedangkan sisanya dipengaruhi oleh faktor-faktor yang lain.

\section{REFERENCES}

[1] Rusman, Pembelajaran Tematik Terpadu. Jakarta: Rajawali Pers, 2016.

[2] K. Hidayati and E. Listyani, "Improving Instruments of Students' Self-Regulated Learning,” J. Penelit. dan Eval. Pendidik., vol. 14, no. 1, pp. 84-100, 2010.

[3] L. Fidiana, S. Bambang, and D. Pratiwi, "Pembuatan dan Implementasi Modul Praktikum Fisika Berbasis Masalah Untuk Meningkatkan Kemandirian Belajar Siswa Kelas XI," Unnes Phys. Educ. J., vol. 1, no. 2, pp. 38-44, 2012.

[4] Darwan and M. Irfadi, "Perbandingan Pemahaman Siswa Antara yang Menggunakan Software Geogebra dengan yang Tidak Menggunakan Software Geogebra pada Pokok Bahasan SPLDV," 2013.

[5] M. S. I. Rahayu, "Pengembangan Media Pembelajaran Berbasis Mobile Learning Pada Platform Android Sebagai Sumber Belajar Untuk Meningkatkan Kemandirian Belajar Dan Hasil Belajar Fisika Peserta Didik Kelas X," Universitas Negeri Yogyakarta, 2017.

[6] E. P. Utomo, From Newbie to Advanced. Yogyakarta: CV Andi Offset, 2012.

[7] J. Attewell and C. S. Smith, Mobile Learning Anytime Everywhere. London: Learning and Skills Development Agency, 2004.

[8] E. A. Wibowo and R. Arifudin, "Aplikasi Mobile Learning Berbasis Android," UNNES J. Math., vol. 5, no. 2, pp. 109-117, 2016.

[9] J. Attewell, Mobile Technologies and Learning. London: Learning and Skills Development Agency, 2005.

[10] H. N. Lengkong, A. A. E. Sinsuw, and A. S. M. Lumenta, "Perancangan Penunjuk Rute Pada Kendaraan Pribadi Menggunakan Aplikasi Mobile GIS Berbasis Android Yang Terintegrasi Pada Google Maps," E-Journal Tek. Elektro dan 
Komput., pp. 18-25, 2015.

[11] A. Juansyah, "Pembangunan Aplikasi Child Tracker Berbasis Assisted-Global Positioning System (A-GPS) Dengan Platform Android," J. Ilm. Komput. dan Inform., vol. 1, no. 1, pp. 1-8, 2015.

[12] A. M. N. Usman, "Pengaruh Metode Kumon Terhadap Kemandirian dan Prestasi Belajar Matematika Siswa Kelas VII Putra SMP Takhassus Nuril Anwar Loano Purworejo Tahun Ajaran 2015/2016," Universitas Muhammadiyah Purworejo, 2016.

[13] D. Rachmayani, "Penerapan Pembelajaran Reciprocal Teaching Untuk Meningkatkan Kemampuan Komunikasi Matematis Dan Kemandirian Belajar Matematika Siswa," J. Pendidik. Unsika, vol. 2, no. 1, pp. 13-23, 2014.

[14] R. D. Puspitasari, "Pengaruh Pembelajaran Berbasis Proyek Terhadap Kemandirian Belajar Fisika Peserta Didik Kelas X SMK Negeri 7 Bandar Lampung," Universitas Islam Negeri Raden Intan Lampung, 2017.

[15] Sugiyono, Metode Penelitian Kuantitatif, Kualitatif, dan R\&D. Bandung: Alfabeta, 2018.

[16] Sugiyono, Metode Penelitian Pendidikan. Bandung: Alfabeta, 2015. 